\title{
MUSLIM WOMEN'S RIGHT TO MARRIAGE DISSOLUTION IN THE CASE OF MISSING HUSBAND: A JURISTIC ANALYSIS ON MISSING PASSENGERS OF MH 370
}

\author{
Tengku Fatimah Muliana Tengku Muda ${ }^{1}$ \\ Azizah Mohd ${ }^{2}$
}

\begin{abstract}
March $8^{\text {th }}$ has marked a catastrophe in Malaysians' calendar as the Malaysia Airlines Flight 370 (MH370) which was a scheduled international passenger flight disappeared while flying from Kuala Lumpur International Airport to Beijing Capital International Airport. The aircraft was carrying 12 Malaysian crew members and 227 passengers from 15 nations. Months have passed, still there is no news nor debris of the unfortunate aircraft found. This incident is one of the many more incidents involving disappeared persons; some have been disappeared for months, while others for years. Narrowing the scope of the discussion, certainly a wife whose husband has been missing for a long time is deprived of her protection, companionship, pleasure of life and financial support. In view of this, the article aims at analyzing the juristic legal opinions specifically in the case of missing husbands
\end{abstract}

1 Lecturer, Centre of Shariah Studies, Faculty of Islamic Contemporary Studies, Universiti Sultan Zainal Abidin, Kuala Terengganu, tg_fatimah@unisza.edu.my

2 Associate Professor, Department of Islamic Law, Ahmad Ibrahim Kulliyyah of Laws, International Islamic University Malaysia, Kuala Lumpur, azizahmohd@ iium.edu.my 
amongst Muslim women. In relation to that, it will then discuss on their right to apply for divorce under the Islamic family law in Malaysia. Classical jurists writings and statutory provisions are gathered and analyzed during the research. The findings indicate that there has been dissenting views among one madhhab (sect) to another on the legal implication of a missing person. Where Malaysia law is concerned, the provision has adopted a more convenient view amongst the jurists which allows a dissolution of marriage under certain specified conditions.

Keywords: missing person, presumption of death, divorce, legal implication, mafqūd

\section{INTRODUCTION}

Shariah has prescribed upon the husband to live in good companionship with their wives. Consequently any harm resulting from the failure to do so is consideral sufficient reason for the dissolution of the marriage bond through divorce by a court judge. Allah says in the Quran:

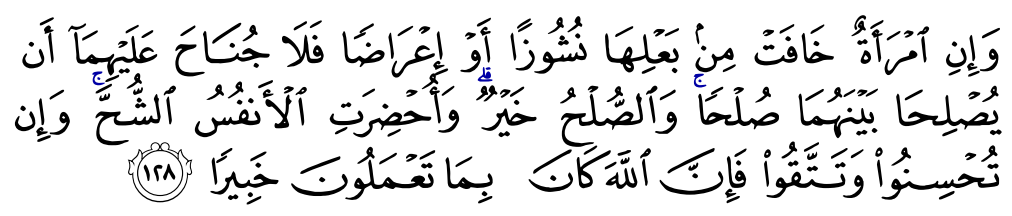

"If a wife fears cruelty or desertion on her husband's part, there is no blame on them if they arrange an amicable settlement between themselves; and such settlement is best; even though men's souls are swayed by greed. But if ye do good and practise self-restraint, Allah is well-acquainted with all that ye do." 3

(Surah al-Nisā', 4: 128)

Based on the verse, al-Qurtubi relates the difference between nushūz and $i$ 'rā in which the former refers 'tabā ' $u d$ ' or avoidance, while the latter refers to refusal to communicate or to associate with. ${ }^{4}$ Ibn Kathīr meanwhile elaborates that when the wife fears that her husband is steering away from

\footnotetext{
3 All translations of al-Quran are based on Ali, Abdullah Yusuf, The Holy Qur'an: Text and Translation (Kuala Lumpur: Islamic Book Trust, 2006). Translation from other resources will be cited accordingly.

4 Al-Qurtubī, Abī 'Abd Allāh Muhammad bin Aḥmad, al-Jāmi ' li Aḥkām al-Qur'ān, Tahqiq: 'Abd Allāh bin 'Abd al-Muḥsin, vol. 7 (Beirūt: Muassalah Dār al-Risālah, 2006), 161.
} 
her or deserting her, she is allowed to forfeit all or part of her rights; such as provisions, clothing, dwellings and so forth and the husband is allowed to accept such concessions from her. ${ }^{5}$ In relation to this verse, it is recorded when Sawdah bint Zam'ah became old, she forfeited her day to 'Aishah, and the Prophet P.B.U.H. used to spend Sawdah's night with 'Aishah. It was reported from Hisham bin Urwah, from his father that 'Aishah said:

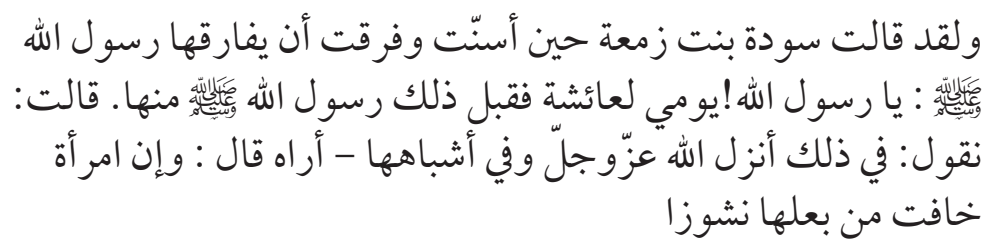

"And when Sawdah feared that the Messenger of Allah might divorce her and she said, 'O Messenger of Allah! Do not divorce me; give my day to Aishah. So the Messenger of Allah accepted that from her. And we would say, concerning that, that it was regarding her and others in her situation, for which Allah revealed: "And if a woman fears desertion from her husband..." 6

It can be inferred that Islam always recognizes the psychological and physical needs of a woman, ${ }^{7}$ and it makes it the wife's right that the husband should not be absent for a long period of time fearing that it will harm her or it will invite malicious slander. The Quran states to the effect;

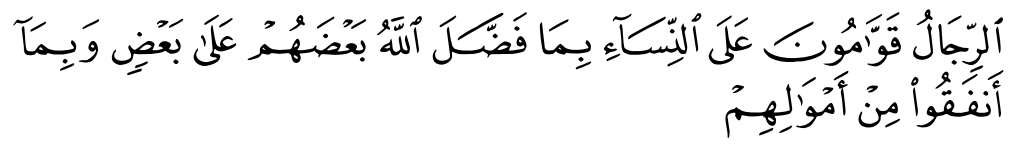

"Men are protectors and maintainers of the women because Allah has given the one more strength than the other and because they support them from their means."

(Surah al-Nisā', 4: 34)

In another verse the Quran states;

5 See Ibn Kathīr, Ismā‘īl bin 'Umar, Tafsīr al-Qur'ān al- 'Aẓīm, vol. 2 (Qāhirah: Dār al-Hadīth, n.d.), 83.

6 Reported by Abū Dāwūd, Kitab al-Nikāḥ, Chapter: Fi al-Qismi bayna al-nisā’i, No. 2135. Hasan Sahih. See Sulaymān bin al-Ash'ath, Sunan Ab̄̄ Dāwūd, in Kutub al-Sittah, ed. Sālih bin 'Abd al-'Aziz al-Shaykh (Dār al-Salām li al-Nashr wa al-Tawzi', 2000), 1380.

7 Ekram \& Rida, M., Blissful Marriage (USA: Amana Publications, 2005), 160. 


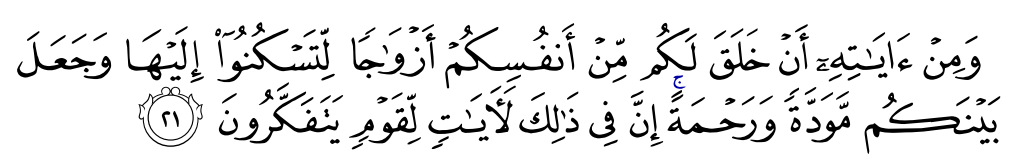

"And among His signs is this, that He created for you mates from among yourselves, that you may dwell in tranquility with them, and He has put love and compassion between your hearts; verily, in that are signs for those who reflect."

(Surah al-Rūm, 30: 21)

The verses established the special nature in a relationship between a man as the husband and the woman as the wife. In the presence of one another, they complement each other with comfort and emotional tranquility. A wife whose husband has been missing for a long time is deprived of her protection, companionship, pleasure of life and financial support. In view of this, hope, despair and sorrow are still surrounding the families and next of kins of the Malaysia Airlines flight 370 (MH370) passengers which had been missing since March 8th 2014. The aircraft was carrying 12 Malaysian crew members and 227 passengers from 15 nations. The unfortunate flight's disappearence and ambiguous loss had drawn the international attention and debates. The government through the Department of Civil Aviation director-general Azharuddin Abdul Rahman officially declared the missing MAS Flight MH370 as having undergone an accident under international aviation rules, and that all 239 passengers and crew aboard were presumed to have lost their lives. ${ }^{8}$ To date, after more than a year of its disappearance, there is still no wreckage of the unfortunate aircraft confirmed found, while the families and the public are still hoping for a miracle. ${ }^{9}$ On the religious turn, Islam discourages a person to continue to be imbued with sadness and sorrow following a loss of loved ones. According to National Fatwa Chairman, Prof. Datuk Dr. Abdul Shukor Husin, the confirmation made by the government is essential and in line with the spirit of Islam to ensure the rights of the heirs such as the distribution of the estate owned by the deceased and the status of the abandoned spouse are given due priority. ${ }^{10}$

\footnotetext{
8 'Announcement of MH370', Department of Civil Aviation of Malaysia, http:// www.dca.gov.my/MH370, 28 January 2015, accessed 31 May 2015.

9 'Setahun Berlalu, Dunia Masih Menantimu MH370', Sinar Harian, http://www. sinarharian.com.my, 6 March 2015, accessed 1 June 2015; 'Setahun Kehilangan MH370', Utusan Online, http://utusan.com.my, 7 March 2015 accessed 1 June 2015; 'Keluarga Penumpang Pesawat MH370 Masih Mengharap Keajaiban', BH Online, http://www.bharian.com.my, 29 January 2015, accessed 1 June 2015.

10 'Hukum Mafqud Tentukan Status Mangsa MH370', Utusan Online, http://utusan. com.my, 1 May 2014, accessed 1 June 2015.
} 
In this sense, the discussion on al-mafqu$d$ had been conducted in varied lenses, particularly concerning the distribution of property. Asmadi Abdullah ${ }^{11}$ related the Islamic jurisprudence principle of al-istishab to the right of succession involving missing persons. Asmadi also discussed on the conflict of jurisdiction in cases of missing person pertaining to distribution of the missing person's estate and probate issues. This is agreed by Mohamed Hadi ${ }^{12}$ (2014) that the variations of the establishment period of death under the Civil and Shariah Court causes difficulty and conflict to the heirs with regards to the distribution of property. Writings by arab scholars are also seen to focus on general discussion of al-mafqu$d$, as the work done by Halafi, ${ }^{13}$ Muhammad $^{14}$ and Saqa. ${ }^{15}$ Only few writings can be seen to focus on spouse of al-mafqüd such as done by Mawardi ${ }^{16}$ who discusses the waiting period of women following the death of husband as well as in the case of presumption of death and missing husband. For that purpose, this article aims to discuss the juristic views as well as provisions of existing Shariah law in Malaysia pertaining to the specific case of $\mathrm{MH} 370$. Classical jurists writings and statutory provisions are gathered to analyze the legal right of a woman to free herself from a marriage tie through a court order when her husband has been missing for a period of time.

In relation to this, the discussion among Islamic jurists on missing husband demonstrates that there are two terms referred to a missing husband in Arabic, which are 'al-ghäib' and 'al-mafqūd'. Someone who has disappeared but is believed to be alive, and is of known place of resident is called al-ghäib. ${ }^{17}$ It is also said that al-ghäib refers to a husband who moves to another country

11 "The Applicability of Usūl al-Fiqh Principle "Istishāb" to the Presumption of Death of a Missing Person in Islamic Law of Succession and Malaysia Law', IIUM Law Journal, 18 (2010): 321-346.

12 Mohamed Hadi, 'Anggapan Kematian al-Mafqud Menurut Undang-undang Sivil dan Syariah: Satu Penilaian Semasa', KANUN, 26/1 (2014): 26-37.

13 Halafi, Jamāl 'Abd al-Wahāb 'Abd al-Ghafār, Ahkam al-Mafqūd fì al-Sharī'ah al-Islāmiyyah: Dirāsat Fiqhiyyah Muqāranah (al-Iskandariyah: Dār al-Jamī'ah al-Jadīdah li al-Nashr, 2003).

14 Muḥammad 'Abd al-Rạ̣īm, Zawjah al-Ghāib, Dirāsat Muqāranah (Qāhirah: Dār al-Salām, 1990).

15 Saqa', Āḥkām al-Ghāib wa al-Mafqūd fì Fiqh al-Islāmī (Dimashq: Dār al-Nawādir, 2008).

16 Mawardī, 'Alī bin Muhammad, 'Iddat al-Wafāt wa Imra'at al-Mafqūd wa alMadkhül biha (Makkah: Wafa' Ma'tuq Hamzah Farrash, 1993).

17 Wizārah al-Awqāf wa Shu'ūn al-Islāmiyyah bi al-Kuwayt, Mawsū'ah alFiqhiyyah, vol. 29 (Kuwayt: Dār al-Ṣafwah, n.d.), 62. 
or place other than the wife's where their house is situated. ${ }^{18}$ Ibn Qudāmah viewed that there are two conditions of 'al-ghaībah: the first one is ghaībah ghayr munqati 'ah which refers to the condition of a person who travels and it is possible to reach him by letter. ${ }^{19}$ Meanwhile ghaībah munqati 'ah explains the condition of al-mafqu $\bar{u}$, of which, according to al-Fatāwa al-Hindiyyah almafqūd refers to a person who has disappeared from his family or his country or has been taken as a prisoner in a battle by the enemies, and is not known whether he is still alive or not. ${ }^{20}$ Thus it seemed that the different scope between al-ghäib and al-mafqūd lies on the awareness on whether he is still alive or not. For the purpose of the discussion, the term 'missing husband' refers to both condition; al-ghäib and al-mafqūd and the implications of both status to their marital tie will be discussed accordingly.

\section{MH370 PASSENGERS ARE CATEGORIZED AS MISSING PEOPLE (AL-MAFQ $\bar{U} D)$}

In this case of MH370, the Fatwa Committee of the National Council for Islamic Religious Affairs Malaysia has held a special discourse (Muzakarah) on March 25th 2014 to determine the legal rules concerning the matter. ${ }^{21}$ The Muzakarah decided that the need to set the period of missing of the passengers before they can be established dead is on the consideration of the authority. This is in accordance with the opinion of the majority of scholars, including school of Shafi, Maliki, Hanafi and Hanbali ${ }^{22}$ with certain requirements.

Based on the legal maxim which is 'elimination of harm' and preservation of the five principles of the objectives of Shariah which is the protection of religion, life, property, progeny and mind, as well as protecting the family and the parties involved, the Muzakarah decided that the situation of the missing passengers in this tragedy does not require a specific length of time as viewed

18 Muhammad al-Shima', al-Mufìd min al-Abhath fì Aḥkām al-Zawāj wa al-Talāq wa al-Mìrath (Damsyiq: Dār al-Qalam, 1996), 147.

19 Ibn Qudāmah, al-Mughni, vol. 7 (Qāhirah: Dār 'Alam al-Kutub, 1980), 488.

20 Al-Fatawā al-Hindiyyah, vol. 2 (Beirūt: Dār Ihyā’ al-Turāth al- ‘Arab̄i, 1986), 299; Al-Buhūti, Manșūr bin Yunus, Kasyāf al-Qinā' 'an Matn Al-Iqnả, vol. 5 (Beirūt: Dār al-Fikr Li al-Tibā'ah wa al-Nashr wa al-Tawzi`), 194.

21 'Muzakarah Khas Jawatankuasa Majlis Fatwa Kebangsaan,' http://www.e-fatwa. gov.my/fatwa-kebangsaan/tragedi-mh370, accessed 25 March 2015.

22 Ramlī, Muḥammad bin Aḥmad, Nihāyah al-Muḥtāj ila Sharh al-Minhāj fĩ al-Fiqh 'ala Madhhab al-Imām al Shäfi 'ī, vol. 6 (Misr: Sharikat Maktabah wa Maṭba'ah Muștafā al-Bābī al-Halābī wa Awlādih, 1967), 28; al-Dusūqī, vol. 2, 431; Ibn 'Ābidīn, vol. 3, 323; Buhūti, vol. 5, 194. 
by the classical scholars. The Muzakarah also agreed that after all the evidence and arguments were reviewed, all passengers of MH370 is categorized as almafqu $\bar{u}$ with a strong probability to be considered dead. The decision made after considering the efforts undertaken to find the missing aircraft with the use of various assets and high-tech communication tools, as well as the views of the experts that the survival of human life is almost impossible after a certain period of reasonable time has passed due to the condition of the vast ocean.

\section{RIGHT OF WIFE TO ASK FOR DIVORCE IN THE CASE OF MISSING HUSBAND}

The jurists are divided in their opinion on the right of a wife to claim for a dissolution in the case of a missing husband. The Shāfi '⿳亠ss, the Zāhirīs and the Hanafis viewed that a dissolution is not justified in the case of missing husband, thus it is not permissible for the wife to claim for a dissolution even if his disappearance causes harm to her. ${ }^{23}$

According to al-Shāfi ' 1 , husband's disappearance shall not be a reason for a divorce. A wife shall never remarry until she is convinced of her husband's death, then should only she begin her 'iddah. ${ }^{24}$ According to al-Syirāzi, there are two opinions in the case of al-mafquid; the opinion of the old school of AlShāfi' $\overline{1}$ (qawl qadìm), ${ }^{25}$ and the new school of al-Shāfi '⿳亠̄ (qawl jadìd). ${ }^{26}$

Al-Shāfi'ī's qawl qadìm views that since fasakh is permissible in the case of inability to perform an intercourse due to al- 'unnah and inability to provide maintenance; hence inability to perform both (intercourse and maintenance) in the case of al-mafqūd should make fasakh more permissible. While al-Shāfi'î's qawl jadìd views that fasakh is not permissible in this case. This is because

23 Al-Shīrāzī, Abū Isḥaq Ibrāhīm bin 'Alī, al-Muhadhdhab, vol. 12 (Beirūt: Dār al-Ma'rifah li al-Tibā'ah wa al-Nashr, n.d.), 94; Ibn Hazm, 'Alī bin Ahmad, alMuḥallā, vol. 7 (Beirūt: Dār al-Fikr, n.d.), 134; Ibn Nujaym, al-Baḥr al-Rāiq Sharh Kanz al-Daqāiq, vol. 5 (Beirūt: Dār al-Ma'rifah li al-Tibā'ah wa al-Nashr, n.d.), 178

24 Al-Shāfi'î, Abī 'Abd Allāh Muḥammad bin Idris, Al-Umm, vol. 5 (Beirūt: Dār al-Fikr li al-Tibā'ah wa al-Nashr wa al-Tawzi', 1983), 239; see also Nawāwī, Raw ̣̦ah al-Ṭālibìn, vol. 8 (Beirūt: al-Maktab al-Islāmī, 1985), 400.

25 Qawl qadìm: the opinion or fatwa issued by al-Shāfi'ī while he was in Baghdad, Iraq.

26 Qawl jadīd: the opinion or fatwa issued by al-Shāfi ‘̄i while he was in Mișr. In some instances (not all), al-Shāfi‘ 1 withdrew his earlier opinions when forming the qawl jadīd. His withdrawing of a view means that it did not remain his madhhab. 
a fasakh in the case of al- 'unnah is permitted on the ground of certainty of the disease, while a fasakh on al-mafqūd is not based on the certainty of his death. $^{27}$

Al-Shirbīni seems to relate his view on the right of a wife to claim for a dissolution as for her right to demand for a sexual intercourse (al-wat'u). He explained that if a wife claims for a dissolution due to his refusal to commit an intercourse, the judge should not allow it since consummation is the right of the husband, and he has the right to refuse it (fa lahu tarakahu). Consequently, a divorce should not be affected in the case of a missing husband for his failure to fulfill an intercourse. ${ }^{28}$

According to Ibn Hazm a fasakh is not at all possible in the case of a missing husband, whether he was lost during a war or not, the wife should maintain patient until his death is confirmed. ${ }^{29}$ Similarly, the Hanafis viewed that a dissolution is not possible until the husband's death is confirmed or until he is presumed to have died according to the natural ages of men in their time and place. ${ }^{30}$

The jurists' opinion is also based on the argument as follows:

i) There is no single verse of the Quran, or evidence from the Prophet P.B.U.H. that permits a dissolution on the ground of a missing husband and that a waiting period or 'iddah is also not compulsory for a wife whose husband's death is not determined. ${ }^{31}$

ii) Based on the narration of al-Mughirah bin Shu'bah that the Prophet P.B.U.H. ordered the wives of al-mafqüd to be patient until there is proof. ${ }^{32}$ Thus if this instruction is made to the wife of al-mafqu$d$ where there is no news of his death or life, then the wife of al-ghäib should serve better in their patience until the husbands return. ${ }^{33}$

iii) The marriage 'aqad is certain (thäbit), and the husband's life or death is uncertain (shak), hence based on the principle of certainty shall not be

\footnotetext{
$27 \quad$ Al-Shīrāzī, vol. 12, 94.

28 Al-Shirbīni, Muḥammad Aḥmad, al-Iqna ‘fi Hall Alfāz Abī Shujja ', vol. 4 (Qāhirah: al-Maktabah al-Tawfiqiyyah, 1998), 415.

29 Ibn Hazm, vol. 7, 134.

30 Ibn Nujaym, vol. 5, 178.

31 Al-Shirbīni, vol. 4, 415.

32 Al-Dār Qutni, 'Alī bin 'Umar, al-Sunan, vol. 3 (Beirūt: Dār Ihya' al-Turāth al'Arabī, 1993), no. 255, 312.

33 Al-Sarțāwī, Mahmud 'Alī, Sharh Qanūn al-Aḥwal al-Shakhṣiyyah al-Urduni, vol. 2 ('Amman: Dār al-Fikr lil Ṭibā'ah wan Nashr, 1997), 469.
} 
removed by doubt, the wife could not claim for a fasakh. ${ }^{34}$

Meanwhile the Mālikis, ${ }^{35}$ the Hanbalis ${ }^{36}$ and the more preferable view among the Hanafis ${ }^{37}$ opined that dissolution is permissible in case of a missing husband, but they differed on the minimum period of his disappearance to enable a wife to claim for a dissolution. The opinion is based on the following arguments:

i) Allah says to the effect:

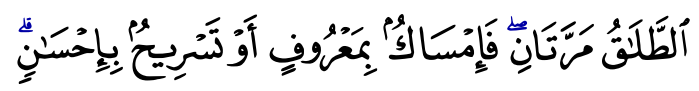

"A divorce is only permissible twice: after that, the parties should either hold together on equitable terms, or separate with kindness."

(Surah al-Baqarah, 2: 229)

It is the custom of the pagan Arabs that a man could divorce his wife thousands of times and revoke it in order to cause harm to her, while there was no limit in this regard. When this grievance was reported to the Prophet P.B.U.H., the above verse was revealed and limited the divorce to three times. ${ }^{38}$ Thus, forcing a wife whose husband has disappeared and is not divorced to remain in a marriage tie is surely not an act of $i h s \bar{a} n$, thus she should be released with kindness.

ii) In another verse, Allah has ordained not to keep wives so as to hurt or harm her. Allah says to the effect:

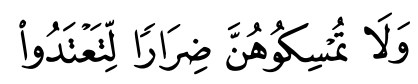

"But do not take them back to injure them, (or) to take undue advantage."

(Surah al-Baqarah, 2: 231)

\footnotetext{
34 Al-Kāsāni, vol. 6, 196.

35 Al-Dardīr, Aḥmad bin Muḥammad bin Aḥmad, al-Sharh al-Ṣaghīr 'ala Aqrab alMasālik, vol. 2 (Beirūt: Mustafa al-Halabi, 1952), 764.

36 Ibn Qudāmah, vol. 8, 143; Al-Buhūti, vol. 5, 193.

37 Ibn 'Ābidīn, Muhammad bin 'Alī, Radd al-Muhtar 'ala Dār al-Mukhtar, vol. 5 (Beirūt: Dār al-Ma‘rifah, 2000), 590.

38 Ibn Kathīr, vol. 1, 160.
} 
Preventing a dissolution of marriage between a missing husband and a wife shall mean to abstain the wife in a way that will harm her. The jurists who viewed that dissolution is not permissible in this matter argued that the verse of the Quran is not considered as adillah tafșiliyyah thus inadmissible, and moreover the verse is revealed to clarify the number of tala $q$. In answering to this, jurists of Malikis and Hanbalis held on the principle adopted by fiqh, 'al-ibrah bi umūm al-lafz la bi khușuṣ al-sabab' (What must be considered is the generality of text wording, not the particularity of the cause of revelation). This means when a text is expressed in a general form, it should be understood as so, although the context of the revelation is specific to a particular point in time. ${ }^{39}$

iii) It is narrated that when the Prophet P.B.U.H. was informed that 'Abd Allāh bin Amru bin al-'As performed fasting during the day and prayer all the night, he said;

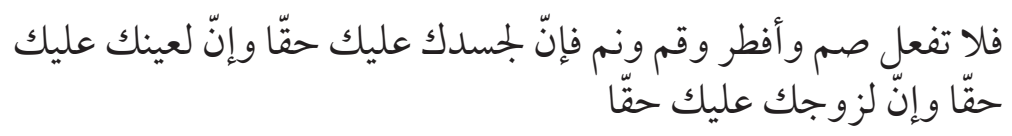

"Don't do that, fast for few days and pray and sleep at night, as your body has a right on you, and your eyes have a right on you, and your wife has a right on you..." 40

Hence among the rights of which Islam has bestowed on a wife over her husband is the right to consummation ( $\left.a l-w a t^{\prime} u\right)$, and if the husband fails to fulfill his obligation, it shall become permissible for the wife to claim for a dissolution. ${ }^{41}$

iv) The Prophet P.B.U.H. forbids any element of harm as he said, 'La darār wa la dirār.' ${ }^{42}$ The absence of the husband may bring harm to the wife and denying her from her right, may cause upon her great ordeal or may lead her to immoral acts, thus the principle of 'al-darār yuzal' (harm must

39 Al-Samarqandi, Mīzan al-Ușūl, vol. 1 (Riyadh: Tawzi` Maktabah al-Ma‘ārif, n.d.), 481.

40 Reported by al-Bukhāri, Kitāb al-Sawm, Bāb Haqq al-Jismi fi al-Sawm, no. 1974. See al-Bukhāri, Muḥammad bin Ismā‘īl, Șaḥ̄ḥ al-Bukhārī, vol. 4 (n.p.: Dār alMa'rifah, n.d.), 217.

41 Ibn Qudāmah, vol. 8, 140-142; Ibn Hajar al-Asqalāni, Ahmmad bin 'Alī, Fatḥ alBārī bi Sharh Șahīh al-Bukhārī, vol. 9 (Beirūt: Dār al-Ma'rifah, n.d.), 299.

42 Reported by Ibn Mājah, Kitab al-Ahkām, Bāb Man bana fi haqqihi ma yaḍuru bijārihi, no. 2340. See Ibn Mājah, Muhammad bin Yazid, Sunan Ibn Mājah, vol. 1 (Beirut: al-Maktabah al-'Ilmiyyah, 1954), 736. 
be eliminated) must be applied. The jurists also relied on several other principles of fiqh such as 'Dar' al-mafāsid awla min jalbi al-manāfi' (the repelling of evil is preferred to the acquisition of benefits) and 'al-darār al-aqwa yuzal bi al-ḍarār al-akhaf' (greater harm must be prevented even at the expense of a lesser harm). Thus even if dissolution is not preferred in Islam, yet harm inflicted on a wife due to the missing husband is far greater, and in order to remove the harm, a fasakh should be more allowable. ${ }^{43}$

v) Based on the principle of qiyās (analogy), the jurists relied that a dissolution due to missing husband is justified as done in the case of ila' ${ }^{44}$ and 'unnah. ${ }^{45}$ They argued that the possibility of infliction of harm and hardship in the case of ila' and 'unnah is lesser than in the case of a missing husband. This is because occurrence of ila' and 'unnah merely affected the spousal intimate relationship, but a wife whose husband is missing suffers a denial in a conjugal relationship, a life protection (al-ri'āyah) and financial maintenance. Hence the wife has a right to be released from the marriage tie. $^{46}$

From the discussion and reasoning given by the jurists, it seems that the Malikis, the Hanbalis and few jurists among the Hanafis have taken into consideration the avoidance of harm as a general principle in order for a wife to apply for a dissolution of marriage in the case of missing husband. Although a dissolution is permissible, the requirement needs to be tendered before a dissolution of marriage can be ordered.

43 Al-Qanuji, Muhammad Șādiq Hussin, Rawḍat al-Nadiyyah, vol. 2 (Beirūt: Dār al-Ma'rifah, 1980), 65.

44 A husband swearing by God or making a declaration to abstain from sexual intercourse with his wife for a period of four months or a longer period. See: Ibn al-Humam, Muḥammad bin 'Abd al-Wāhid, Sharh Fatḥ al-Qadīr, vol. 4 (Beirūt: Dār al-Kutub al-'Ilmiyyah, n.d.), 189.

45 Inability of the husband to perform sexual intercourse due to impotency. See: Ibn al-Humam, vol. 4, 297.

46 Ibn Rushd, vol. 2, 52. 


\section{Other Requirements for a Marriage Dissolution in the Case of Missing Husband}

In allowing a dissolution of marriage in the case of missing husband, the jurist have outlined several requirements before a dissolution shall be ordered.

i) Infliction of harm (husul al-darār): A mere disappearance of the husband without causing any hardship or harm to the wife is insufficient to justify a divorce. ${ }^{47}$ According to Malikis, al-darār here also refers to the wife fearing herself of committing immoral acts or adultery. ${ }^{48}$ According to a more rigid view among the Malikis, before a judge can separate them, the husband must also be proven to intentionally leave the wife in order to harm her. Should the husband proves the contrary, then there should be no dissolution although the wife claims his disappearance harms her. ${ }^{49}$

ii) Valid excuse (al-'Uzru): According to the Hanbalis, in order for a dissolution to take place, the husband's disappearance must not due to some valid reasons such as studying abroad, or running a business. If that is the case, then the judge shall not separate them. ${ }^{50}$ This is in line with the principle of 'al-darūrat tubīhu al-mahẓūrat' or necessity renders prohibited things permissible.

The Malikis, on the other hand viewed that a dissolution shall be ordered if the disappearance of the husband harm the wife, regardless whether the disappearance is due to a valid reason or not. ${ }^{51}$

iii) Order from the judge following a request from the wife: It is the right of the wife to claim for a divorce in the case of a missing husband if his disappearance causes harm to her. However, if she is willing to wait for him, then no dissolution shall be granted. ${ }^{52}$ If she can no longer bears his disappearance, then she shall bring the matter to the judge, and the judge

47 'Amru, 'Abd al-Fattāh, al-Qarārāt al-Qadā'iyyah fì Ahwāl al-Shakhșiyyah ('Amman: Dār al-Yamman, 1990), 49.

48 Al-Mawsū'ah al-Kuwaytiyyah, vol. 29, 64; Wahbah al-Zuhaylī, al-Fiqh al-Islāmī wa Adillatuh, vol. 7 (Qāhirah: Dār al-Fikr, Qāhirah, 1984), 533.

49 Al-'Adawi, Hāshiyah al- 'Adaw̄̄, vol. 4 (Beirūt: Dār al-Kutub al-'Ilmiyyah, n.d.), 93.

50 Al-Buhūti, vol. 5, 194.

51 'Illish, Muhammad bin Ahmad, Manh al-Jalīl Sharh 'ala Mukhtașar al-Khalīl, vol. 2 (Beirūt: Dār al-Kutub al-'Ilmiyyah, n.d.), 313.

52 Al-Khurshi, Abū 'Abd Allāh Muhammad, Hāshiyah al-Khurshi 'ala Mukhtasar Khalīl, vol. 4 (Beirūt: Dār al-Kutub al-Ilmiyyah, 1995), 94. 
will, according to his discretion and ijtihād gives his judgment. ${ }^{53}$

iv) Written notification to the missing husband: In the case where the husband's whereabouts is known, the judge shall write to the husband and order him to reconcile with the wife, or to bring the wife to his place, or to divorce the wife. The judge will give him days of respite which he thinks fit and if the husband still fails to abide his order after the days have passed, or that the whereabouts of the husband is still unknown after due inquiry and it becomes impossible to reach him, then the judge shall order for a dissolution. ${ }^{54}$

v) The husband is at a country other than the wife's: If the husband moves to a place or disappear within the state or country where their matrimonial home is, it is not sufficient to justify a divorce due to the lack of the element of darār. Similarly, if the wife is the one who moves out or disappear to another country, she shall not be entitled for a divorce. ${ }^{55}$

\section{Type of Dissolution of Marriage}

The jurists who permit a dissolution on the ground of a missing husband differed in their opinion on the type of divorce affected in such case. According to the Malikis, it is an irrevocable divorce ( $\operatorname{tal} \bar{a} q b \bar{a}^{\prime} i n$ ), and all types of divorce by the judge order is $t a l \bar{a} q b \bar{a}{ }^{\prime} i n$, except for a divorce in a case of ila ${ }^{56}$ and of an insolvent husband which affected a revocable divorce (talāq raj $\left.^{~}{ }^{\imath}\right) .{ }^{57}$ The Hanbalis viewed that a divorce in this matter affected a fasakh, and not tala q. This is based on the reason that it is a divorce applied by the wife, and every divorce applied by a wife affected a fasakh and not tala $q .{ }^{58}$

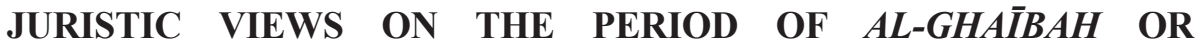 DISAPPEARANCE}

On the period of the disappearance of the husband, the most preferable view among the Malikis maintains that a wife should wait at least one full year

\footnotetext{
53 Ibn Qudāmah, vol. 8, 143.

54 Al-Hațāāb, Mawāhib al-Jalīl, vol. 4 (Libya: Maktabah al-Najah, n.d.), 146; Ibn Qudāmah, vol. 8, 143.

55 'Amru, 'Abd al-Fattāh, 50.

56 Note 44

57 Al-Dusūqī, Shams al-Dīn Muḥammad, Hāshiyah al-Dusūqī 'ala Sharh al-Kabīr, vol. 2 (Qāhirah: Dār Iḥya al-Kutub al-'Alamiyyah, n.d.), 431.

58 Ibn Qudāmah, vol. 8, 143.
} 
(sanah kämilah mustamirrah düna inqita ) on the expiry of which she can apply for a dissolution. A minority view among them opined that she should wait for two years and three months the least. ${ }^{59}$

Meanwhile the Hanbalis view that a wife should at least wait for six months before she could apply for a dissolution. ${ }^{60}$ This is based on a narration from Zayd bin Arqam that once 'Umar al-Khatțab heard a woman reciting poetry about her husband who was away on jihäd. 'Umar then asked her daughter, Hafsah on how long a woman can be patient without her husband. She replied six months, upon which 'Umar issued a decree to all his commanders to relieve every war after every six months. ${ }^{61}$

\section{Presumption of Death of a Missing Husband}

The jurists however are unanimous in that dissolution of marriage can be applied if the husband has been presumed dead by a declaration. There are jurists who based their opinion on the period of waiting at a normal life-span of a man's life. However, the jurists differ in determining the life-span of a man because the life-span itself may depends on many factors as including country of residence in which the person lives. As for example, it is asserted in al-Fatawā al-Hindiyyah that al-mafqūd shall not be separated from his wife and shall only be presumed to be dead at the age of ninety years. ${ }^{62}$

According to al-Shirbīnī, after a lapse of time that renders strong probability that a person in the same condition would not survive, the court may decree a presumption of death. This is done through the process of $i j t i h \bar{a} d^{63}$ in which

\footnotetext{
59 Al-Hațāāb, vol. 4, 156; al-Dardīr, vol. 2, 746.

Derived from the root word jahada, ijtihād literally means striving, or self exertion in any activity which entails a measure of hardship. It would thus be in order to use jahada in respect of one who carries a heavy load, but no so if he carries only a trivial weight. Juridically, ijtihād is defined as the application by a jurist of all his faculties either in inferring the rules of Sharī ah from their sources, or in implementing such rules and applying them to particular issues. It is also defined as the total expenditure of effort made by a jurist in order to infer, with a degree of probability, the rules of Sharī ah from their detailed evidence in the sources. For more on ijtihād, see Yūsuf al-Qaraḍāwī, al-Ijtihād fi al-Sharī'ah al-Islāmiyyah (Kuwayt: Dār al-Qalam, 1989).
} 
the duration of disappearance is not determined. This is the most sound view, ${ }^{64}$ and it is also said that the period of disappearance should be seventy years, eighty years, or ninety years and some even said until one hundred and twenty years. ${ }^{65}$

Ibn Qudāmah in this matter elaborates that if his disappearance normally indicates a misfortune would have happened to him such as he has gone to the mosque during the day or night but failed to return home, or he has gone to a nearby place but did not return and have never been heard of again, or he has disappeared amidst the dessert, or the battlefield, hence in this case the wife shall wait for him for four years before she can observe the iddah. ${ }^{66}$ Meanwhile if his disappearance happened during a safe business trip, or during his studies or vacation, the wife shall wait until he would normally be presumed dead, which is at the age of 90 years old. ${ }^{67}$

The Maliki jurists have adopted a more convenient view of the matter. According to them, if a husband disappeared in an Islamic country and not during a certain pandemic, a wife shall bring the case to the judge, and the judge will act accordingly to search and trace the husband. And if he cannot be found, the wife will have to wait for four years before the husband can be presumed dead. ${ }^{68}$

\section{THE LAW ON MISSING HUSBAND UNDER THE ISLAMIC FAMILY LAW IN MALAYSIA}

It is not an easy task to determine the ruling that will best promote good or best prevent harm. However the importance and generality of the principle cannot be over stated. The Shariah is intended to serve the best interest of mankind as a whole and at all time, not the interest of a particular racial or social group. The concept of best interest encompasses the spiritual and mental well-being of all people in the present and the future. As well as seeking the best interests of mankind as a whole, Islamic legislation is directed towards avoidance of harm. In relation to that, the Islamic Family Law (Federal Territories) Act 1984 (Act 303) (herein after referred to as IFLA) ${ }^{69}$ provided a remedy for a wife to apply for a dissolution of marriage in the case of a missing husband

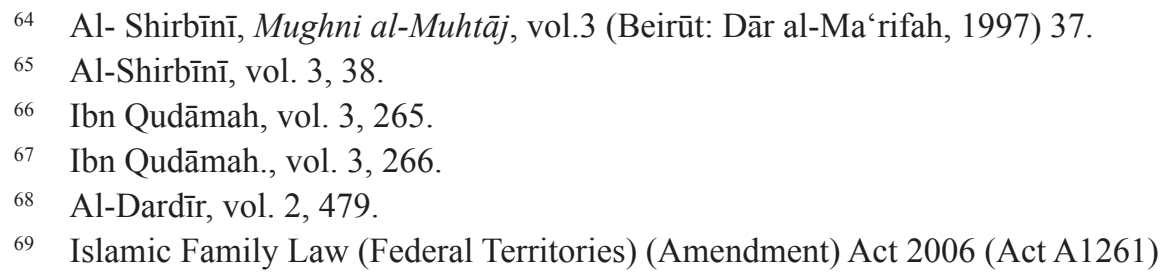


specifically under section 52. In the light of the provision, a woman or man married in accordance with Hukm Syara ' shall be entitled to obtain an order for the dissolution of marriage or fasakh if the whereabouts of the husband or wife have not been known for a period of more than one year; or if the husband or wife has been sentenced to imprisonment for a period of three years or more. In the case of imprisonment, subsection 2 of the provision stated that no order shall be made until the sentence has become final and the husband or wife has already served one year of the sentence.

In the case of presumption of death, section 52 of IFLA also provides that if a husband of any woman has died, or is believed to have died, or has not been heard of for a period of four years or more, and the circumstances are such that he ought, for the purpose of enabling the woman to remarry, to be presumed in accordance with Hukm Syara ' to be dead, the court may, on the application of the woman and after such inquiry as may be proper, issue in the prescribed form a certificate of presumption of death of the husband and the court may on the application of the woman make an order for the dissolution of marriage or fasakh. This is supported by Section 80 of the Shariah Court Evidence (Federal Territories) Act, 1997 which provides that when the question is whether a man is alive or dead, and it is proved that he has not been heard of for four years by those who would naturally have heard of him if he had been alive, the burden of proving that he is alive is shifted to the person who affirms it. The Shariah Court in Malaysia clearly adopts the view of the Malikis and the Hanbalis in determining the years to be observed. Interestingly, in the case of Talib Saari, ${ }^{70}$ the al-mafqūd had been missing since 1972. The learned judge of Shariah Court in Kuala Terengganu observed that 'the fact that there had been a lapse of time since the al-mafqu$d$ had been missing, whereby if the missing person is still alive in 2004, he should already aged 73 years old, an age where a person normally presumed to pass away'. Hence the consideration to determine a death of a man can be seen given to the life-span of a normal person. While in another case of Rizwan bin Ibrahim, ${ }^{71}$ it appears that the Civil Court judge stated that it has jurisdiction to declare a Muslim's presumption of death since such a declaration constitutes part of the administration of estate which is listed under item 4(e) of Federal List in the Federal Constitution. In determining the waiting period before one's death is to be presumed, the court refers to section 108 of the Malaysian Evidence Act, where a person is presumed dead if he is not heard for 7 years by those who would naturally have heard of him if he had been alive. Prior to the amendment made to the Shariah Laws, the period of disappearance before a declaration of death can be applied in the

$70 \quad$ [2010] 1 CLJ (Sya) 493.

71 [2002] 418 MLJU 1. 
Shariah Court is also seven years. It could be submitted that the reason for this amendment might owes to the fact that in a borderless world and technology today, tracing a missing person has become possible and 'easier'. Therefore if nothing is unheard of after four years, it presumably means that the missing person is likely dead.

Following the decision of the National Fatwa and the official declaration made by the government that everyone on board had perished, the status of Muslim marriage of MH370 victims may only be determined by the Shariah Court. Hence if the spouse of a victim intends to dissolve the status of marriage, she may apply for fasakh on the grounds that the spouse had disappeared for more than a year or may apply to the court for the Presumption of Death declaration. To reiterate, the Muzakarah of National Fatwa Committee had declared the missing passengers of $\mathrm{MH} 370$ as al-mafqu$d$ with a strong probability to be considered dead and that this unfortunate tragedy does not require a specific length of time as viewed by the Muslim scholars. It seems that, this arises the issue on whether in this specific case, the Shariah Court would determine the period of disappearence as decided by the National Fatwa and to decide on presumption of death as declared by the government, or accordingly to decide based on the existing legal provisions.

\section{CONCLUSION}

On the basis of the above discussion, it is always an appraisal that the remarkable power of the Shariah is the ability to adjust to different situations in order to serve its overall purpose of promoting the good and preventing the harmful. It can be seen that although it has been the tendency in Malaysia to adopt the Shāfi'i view, yet the Act has been carefully enacted taking into account that a wife whose husband is missing suffers not only a denial in a conjugal relationship, but a life protection (al-ri 'áyah) and financial maintenance. In the case of the whereabouts of the husband is not known or in the case of imprisonment of the husband, the Act has adopted the most preferable view among the Malikis which maintains that a wife should wait at least for one full year. The act has also adopted the view of the Malikis and the Hanbalis in terms of the waiting period before a person can be presumed to be dead which is at four years. If the Act adopted the stricter view of Shāfi'ìs for instance, which viewed that a dissolution is not possible until the husband is believed or is presumed to be dead and the waiting period should be between seventy to one hundred and twenty years, it is feared that the law will inflict hardship on the wife especially in this age where slander and defamation is easily spread to the cloud. In this sense, it could be pointed that: 
i) The role of ijtihād is crucial to be the main instrument of interpreting the divine revelation and relating it to the changing conditions ${ }^{72}$ or uruf $^{73}$ of the Muslim community in its aspirations to attain justice;

ii) In order to invoke the presumption of death, two basic facts must be proved that is; that the person must not have been heard for four years, and that he must not have been heard during that time by those who would naturally have heard him;

iii) Based on the particular case of MH370, reference should be made to the legal maxim derived from the Prophet's saying, "there is no harm, nor return of harm in Islam". Any harmful condition that can trigger harm is prohibited in Islamic law;

iv) While recognition and due respect is given to the views of jurists, there is still room to consider a period best suited this particular case in order to avoid harm and to attain the maslahah (benefit), especially in the matter of missing legal nas.

\section{REFERENCES}

Al-'Adawī, Hāshiyah al- 'Adaw̄̄ (Beirūt: Dār al-Kutub al-Ilmiyyah, n.d.).

'Amru, 'Abd al-Fattah, al-Qararāt al-Qaḍ̄'iyyah fì Ahwāl al-Shakhṣiyyah ('Amman: Dār al- Yamman, 1990).

Azharuddin Abd. Rahman, 'Announcement of MH370', Department of Civil Aviation of Malaysia, http://www.dca.gov.my/MH370, 28 January 2015.

Bernama, 'Keluarga Penumpang Pesawat MH370 Masih Mengharap', BH Online, http://www.bharian.com.my, 29 January 2015.

Bernama, 'Setahun Berlalu, Dunia Masih Menantimu MH370', Sinar Harian, http://www.sinarharian.com.my, 6 March 2015.

Al-Buhūti, Mansur bin Yunus bin Idris, Kasyāf al-Qina' 'an Matn al-Iqna' (Beirūt: Dār al-Fikr Lil Tibā'ah wa Nasyr wa al-Tawzi’, 1982).

72 See Mansi, Muhammad Qāsim, Taghayyur al-Zurūf wa Athāruh fi Ikhtilāf alAhkām fi al-Sharī'ah al-Islāmiyyah (Qāhirah: Dār al-Salām lil-Tibā'ah wa a;Nashr wa al-Tawzi‘ wa al-Tarjamah, 2010)

73 'Uruf constitutes a behavior patterns and cultural values and norms, including acts or words used in a group of people which developed over time. According to Ibn Qayyim 'uruf is dependent to the change of time, place, circumstances and habits of man or of its members. In social science studies 'urf is known as 'social change' although the definition is not left undebated. See: Muḥammad Mușțafā Shalabī, Ușūl al-Fiqh al-Islāmī (Beirūt: Dār al-Nahdah al-'Arabiyyah, 1986), 331. 
Al-Bukhārī, Muhammad bin Ismā‘̄il, Șah̄̄h al-Bukhārī (n.p.: Dār al-Ma'rifah, 1974).

Al-Dār Qutni, 'Alī bin 'Umar, al-Sunan (Beirūt: Dār Ihya' al-Turāth al-'Arabī, 1993).

Al-Dardir, Aḥmad bin Muḥammad bin Aḥmad, al-Sharh al-Ṣaghīr 'ala Aqrab al-Masālik (Beirūt: Mușțafā al-Halab̄i, 1952).

Al-Dusūqī, Shams al-Dīn Muḥammad, Hāshiyah al-Dusūqī 'ala Sharh alKabīr (Qāhirah: Dār Ihyā’’ al-Kutub al-'Alamiyyah, n.d).

Al-Fatawā al-Hindiyyah (Beirūt: Dar Ihya’ al-Turath al-Arabi, 1986).

Halafi, Jamāl 'Abd al-Wahāb 'Abd al-Ghafār, Ahkām al-Mafqūd fì al-Sharī'ah al-Islāmiyyah: Dirāsat Fiqhiyyah Muqāranah (al-Iskandariyah: Dār alJami'ah al-Jadīdah li al-Nashr, 2003).

Al-Hattab, Mawāhib al-Jalīl (Libya: Maktabah al-Najah, n.d.).

Hashnan Abdullah, 'Hukum Mafqud Tentukan Status Mangsa MH370', Utusan Online, http://utusan.com.my, 1 May 2014.

Ibn 'Ābidīn, Muhammad bin 'Alī, Radd al-Muhtar 'ala Dar al-Mukhtar, vol. 5 (Beirūt: Dār al-Ma'rifah, 2000).

Ibn al-Humam, Kamal al-Dīn bin 'Abd al-Wahid, Fath al-Qadīr (Beirūt: Dār al-Fikr, n.d.)

Ibn Hajar al-Asqalān̄̄, Aḥmad bin 'Alī, Fatḥ al-Bārī bi Sharh Ṣah̄ịh al-Bukhārī (Beirūt: Dār al-Ma'rifah, n.d.).

Ibn Hazm, 'Alī bin Aḥmad, al-Muhalla (Beirūt: Dār al-Fikr, n.d.).

Ibn Kathir, Tafsīr al-Qur 'ān al- 'Ażìm (Qāhirah: Dār al-Hadīth, n.d.).

Ibn Mājah, Muhammad bin Yazid, Sunan Ibn Mājah (Beirut: al-Maktabah al'Ilmiyyah, 1954).

Ibn Nujaym, al-Bahr al-Rā 'iq Sharḥ Kanz al-Daqā'iq (Beirūt: Dār al-Ma'rifah li al-Tibā'ah wa al-Nasyr, n.d.).

Ibn Qudāmah, Abū Muhammad 'Abd Allāh, al-Mughnī (Qāhirah: Dar 'Alam al-Kutub, 1980).

'Illish, Muḥammad bin Aḥmad, Manh al-Jalīl Sharh 'ala Mukhtasar al-Khalīl (Beirūt: Dār al-Kutub al-'Ilmiyyah, n.d.).

Al-Kāsāni, Abī Bakr Ibn Su’ud, Badāi ‘ Șanāi ‘ (Beirūt: Dār Iḥya’ al-Turāth al-'Arabī, 2000).

Al-Khurshi, Abū 'Abd Allāh Muḥammad, Hāsyiah al-Khurshi 'ala Mukhtasar Khalīl (Beirūt: Dār al-Kutub al-'Ilmiyyah, 1995). 
Mansi, Muhammad Qāsim, Taghayyur al-Zurūf wa Athāruh fi Ikhtilāf alAḥkām fi al-Sharī'ah al-Islāmiyyah (Qāhirah: Dār al-Salām li al-Tibā'ah wa al-Nashr wa al-Tawzi' wa al-Tarjamah, 2010)

Maward̄̄, 'Alī bin Muḥammad, 'Iddat al-Wafāt wa Imra'at al-Mafqūd wa alMadkhūl biha (Makkah: Wafa' Ma’tuq Hamzah Farrash, 1993).

Mohamad Asmadi Abdullah, 'The Applicability of Usūl al-Fiqh Principle "Istishāb" to the Presumption of Death of a Missing Person in Islamic Law of Succession and Malaysia Law', IIUM Law Journal, 18 (2010): 321-346.

Mohamed Hadi Abd Hamid, 'Anggapan Kematian al-Mafqud Menurut Undang-undang Sivil dan Syariah: Satu Penilaian Semasa', KANUN, 26/1 (2014): 26-37.

Muḥammad 'Abd al-Rahīm, Zawjah al-Ghā'ib: Dirāsat Muqāranah (Qāhirah: Dār al-Salām, 1990)

Muhammad al-Shima', al-Mufìd min al-Abhāth fì Ahkām al-Zawāj wa alȚalāq wa al-Mīrath (Damsyiq: Dār al-Qalam, 1996).

Al-Nawawī, Rawḍh al-Țālibīn (Beirūt: al-Maktab al-Islāmī, 1985).

Al-Qanuji, Muhammad Sadiq Hussin, Rawdat al-Nadiyyah, vol. 2 (Beirūt: Dār al-Ma'rifah, 1980).

Al-Qurțubī, Abī 'Abd Allāh Muḥammad bin Aḥmad, al-Jāmi' li Aḥkām alQur'ān, tahqiq: 'Abd Allāh bin 'Abd Muhssin, vol. 7 (Beirūt: Muassasah Dār al-Risālah, 2006).

Sālih bin 'Abd al-'Aziz al-Shaykh (ed.), Kutub al-Sittah (Dar al-Salām li alNashr wa al-Tawzi', 2000)

Al-Samarqandī, Mizān al-Ușūl (Riyāḍ: Tawzi’ Maktabah al-Ma'arif, n.d.).

Saqa, 'Abd al-Mun'im Fāris, Ahkām al-Ghāib wa al-Mafqūd fì Fiqh al-Islāmī (Dimashq: Dār al-Nawadir, 2008).

Al-Shāfi'î, Ab̄̄ 'Abd Allāh Muḥammad bin Idris, al-Umm (Beirūt: Dār al-Fikr li al-Tibā 'ah wa al-Nashr wa al-Tawzi', 1983).

Shalabī, Muḥammad Muṣțafā, Ușūl al-Fiqh al-Islāmī (Beirūt: Dār al-Nahdah al-'Arabiyyah, 1986), 331

Al-Shīrāzi, Abū Isḥāq Ibrāhīm bin 'Alī, al-Muhazzab (Beirūt: Dār al-Ma'rifah li al-Tibā 'ah wa al-Nasyr, n.d.).

Al-Shirbīnī, Muḥammad Aḥmad, al-Iqna' fì Hall Alfāz Abī Shuja ' (Qāhirah: Al-Maktabah al-Tawfĩqiyyah, 1998).

Al-Shirbīni, Mughni al-Muhtājilla Ma'rifati Ma'ānī Alfāz al-Manhāj, vol.3 (Beirut: Dar al-Ma'rifah, 1997) 
Wahbah al-Zuhaylī, al-Fiqh al-Islāmī wa Adillatuh (Qāhirah: Dār al-Fikr, 1984).

Wayan Suparta, 'Setahun Kehilangan MH370', Utusan Online, http://utusan. com.my, 7 March 2015.

Wizārah al-Awqāf wa Shu'ūn al-Islāmiyyah bi al-Kuwayt, Mawsū'ah alFiqhiyyah (Kuwayt: Dār al-Șafwah, n.d.).

Yūsuf al-Qaraḍāwī, al-Ijtihād fì al-Sharī'ah al-Islāmiyyah (Kuwayt: Dār alQalam, 1989).

\section{Statutes}

Islamic Family Law (Federal Territories) Act 1984 (Act 303).

Islamic Family Law (Federal Territories) (Amendment) Act 2006 (Act A1261).

Shariah Court Evidence (Federal Territories) Act, 1997. 
Jurnal Syariah, Jil. 23, Bil. 3 (2015) 495-516 